\title{
ONE MORE PIECE IN THE GENUS PUZZLE: A NEW SPECIES OF IBEROBATHYNELLA SCHMINKE, 1973 (SYNCARIDA, BATHYNELLACEA, PARABATHYNELLIDAE) FROM THE IBERIAN PENINSULA
}

\author{
A. I. Camacho*
}

\begin{abstract}
A new Iberian species of the genus Iberobathynella is described from the groundwater of Ojo Guareña cave, in the north of Spain (Burgos).

The new species belongs to the subgenus Espanobathynella and presents a unique combination of characters, as follow: female thoracopod 8 with wrinkled cuticle and 1 tooth (the rest of species in this subgenus show a smooth cuticle); seven-eight spines on the furca; 10-12 spines on the sympod, four barbed setae on the exopod and an unarmed endopod of the uropod; labrum with 9 main teeth in the female and 8 in the male; maxilla with one, four and 15 setae on its three segments, respectively; seven teeth on the distal segment of the maxillule; seven teeth on the pars incisiva and seven-nine teeth on the pars molaris of the mandible and antennule with 7 segments.
\end{abstract}

Keywords: Taxonomy, Crustacea, Iberobathynella, groundwater, Iberian Peninsula, cave.

\section{RESUMEN}

Una pieza más de un género puzzle: una nueva especie de Iberobathynella Schminke, 1973 (Syncarida, Bathynellacea, Parabathynellidae) en la Península Ibérica

Se describe una nueva especie del género Iberobathynella (consta de 21 especies endémicas de la Península Ibérica) encontrada en la cueva más grande de España, Ojo Guareña (Burgos).

La nueva especie pertenece al subgénero Iberobathynella (Espanobathynella) compuesto por 4 especies, contando ésta. Este subgénero sólo se había encontrado hasta la fecha en 2 áreas muy pequeñas de Asturias y Cantabria, y siempre en agua subterránea de cuevas.

La nueva especie presenta una combinación de caracteres única: el pereiopodo 8 de la hembra tiene la cutícula rugosa (el resto de especies del subgénero la tiene lisa) y una sola fanera; tiene 7-8 espinas en la furca; el simpodio del urópodo consta de 10-12 espinas, tiene 4 sedas ciliadas en el exopodio y carece de sedas en el endopodio; el labro con 9 dientes principales en la hembra y 8 en el macho (número habitual en el género); la maxila tiene 1, 4 y 15 sedas, respectivamente, en sus 3 segmentos; la maxílula consta de 7 dientes en el segmento distal; la mandíbula tiene 7 dientes en la pars incisiva y entre 7 y 9 en la pars molaris, y la anténula tiene 7 segmentos.

Palabras clave: Taxonomía, Crustacea, Iberobathynella, agua subterránea, Península Ibérica, cueva.

* Museo Nacional de Ciencias Naturales. José Gutiérrez Abascal 2. 28006- Madrid (Spain). e-mail: mcnac22@mncn.csic.es 


\section{Introduction}

With the discovery of one more new species, the tribe Iberobathynellini (Camacho and Serban, 1998) now comprises 26 species in the Iberian Peninsula and four in the rest of the world (three in North America and one in North Africa). This makes it the most diverse and studied group of the family Parabathynellidae (Crustacea, Syncarida, Bathynellacea) (Camacho \& Serban, 2000; Camacho, 2003b, c, 2005).

Of the 20 species of iberobathynellids known to date, none shows the combination of characters present in the new species described here. The new species belongs to the genus Iberobathynella Schminke, 1973 (with 21 species) (see table 1), and to the subgenus Espanobathynella Camacho et Serban, 1998 (with four species). This is the first time that this subgenus has been found in Burgos, and the especies has been named $I$. (E.) burgalensis n.sp. for that reason. This subgenus is the least diversified of the genus since it includes only three species, with a very limited distribution, known from the Eastern part of Asturias (Picos de Europa) and the Sierra de la Collada (Asturias and Cantabria). The other subgenus present in this area, Asturibathynella, comprises 11 species showing a broader distribution.

This discovery is also relevant for the investigation of the group from a phylogenetic point of view. Some of these new combinations of characters give continuity to the range of currently known character series and fill in gaps which will be very useful in resolving relationships between species (Camacho et al., 1997, 2000; Guil \& Camacho, 2001).

\section{Methods}

The specimens studied occurred in one sample obtained from Burgos, North of Spain.

The material was collected with a $0.1 \mathrm{~mm}$ mesh hand net (plankton type) from water in a small pool in a cave.

Table 1.- Species of the genus Iberobathynella Schminke, 1973.

Tabla 1.- Especies del género Iberobathynella Schminke, 1973.

\begin{tabular}{|c|c|c|c|}
\hline Subgenus & Species & Author & Country \\
\hline (Iberobathynella) & & Schminke 1973 & \\
\hline (Iberobathynella) & lusitanica & (Braga, 1949) & Portugal \\
\hline (Iberobathynella) & barcelensis & (Noodt and Galhano, 1969) & Portugal \\
\hline (Iberobathynella) & valbonensis & (Galhano, 1970) & Portugal and Spain \\
\hline (Iberobathynella) & gracilipes & (Braga, 1960) & Portugal \\
\hline (Iberobathynella) & paragracilipes & Camacho et Serban,1998 & Spain \\
\hline (Espanobathynella) & & Camacho et Serban, 1998 & \\
\hline (Espanobathynella) & espaniensis & Serban et Comas, 1978 & Spain \\
\hline (Espanobathynella) & cantabriensis & Camacho et Serban, 1998 & Spain \\
\hline (Espanobathynella) & magna & Camacho et Serban, 1998 & Spain \\
\hline (Espanobathynella) & burgalensis sp. $\mathrm{n}$. & & Spain \\
\hline (Asturibathynella) & & Camacho et Serban, 1998 & \\
\hline (Asturibathynella) & asturiensis & Serban et Comas, 1978 & Spain \\
\hline (Asturibathynella) & parasturiensis & Camacho et Serban, 1998 & Spain \\
\hline (Asturibathynella) & cavadoensis & (Noodt and Galhano, 1969) & Portugal and Spain \\
\hline (Asturibathynella) & ortizi & Camacho, 1989 & Spain \\
\hline (Asturibathynella) & rouchi & Camacho and Coineau, 1987 & Spain \\
\hline (Asturibathynella) & imuniensis & Camacho, 1987 & Spain \\
\hline (Asturibathynella) & serbani & Camacho, 2003 & Portugal \\
\hline (Asturibathynella) & guarenensis & Camacho, 2003 & Spain \\
\hline (Asturibathynella) & celiana & Camacho, 2003 & Spain \\
\hline (Asturibathynella) & lamasonensis & Camacho, 2005 & Spain \\
\hline (Asturibathynella) & cornejoensis & Camacho, 2005 & Spain \\
\hline Unknown & pedroi & Camacho, 2003 & Portugal \\
\hline
\end{tabular}




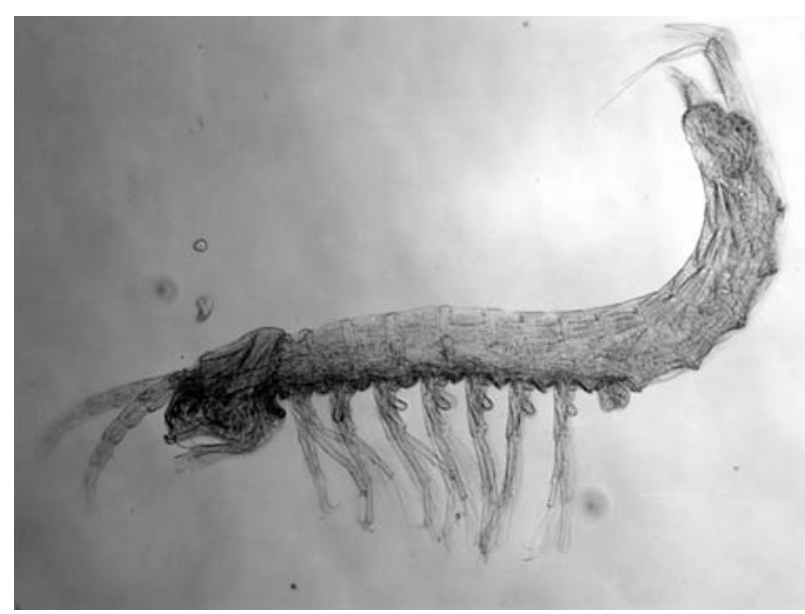

Fig. 1.- Iberobathynella (Espanobathynella) burgalensis n.sp., holotype male.

Fig. 1.- Fotografía óptica del holotipo (macho) de Iberobathynella (Espanobathynella) burgalensis $\mathrm{n} . \mathrm{sp}$.

All specimens comprising the type series were completely dissected, and kept as permanent preparations (special metal slides, glycerine gelatine stained with methylene blue as mounting medium). Anatomical examinations were performed using an oil immersion lens $(100 \mathrm{X})$. The descriptions are based on the type series. The material is deposited in the Museo Nacional de Ciencias Naturales, Madrid (MNCN).

\section{Systematic account}

Genus Iberobathynella Schminke, 1973

Subgenus Espanobathynella Camacho et Serban, 1998

TYPE SPECIES: Iberobathynella (Espanobathynella) espaniensis Serban et Comas i Navarro, 1978.

Diagnosis: Pars incisiva of the Mandible (Md.) with four-five teeth and dentate lobe (proximal endite or pars molaris) with six-eight claws. Maxillule (Mx.I) with seven teeth on the distal endite. Thoracopods (Ths): Exopod (Exp.) of the first pair bi or uni-segmented, with four and three setae respectively; bi-segmented in the other pairs, with four setae. Thoracopod 8 (Th 8) male: external lobe with rectangular lateral face and with a sloping main axis. Uropod: sympod with seven-13 spines; endopod (endp.) with one seta; exopod (exp.) with four-five setae. Furca with seven-10 spines. Anal operculum not pronounced.

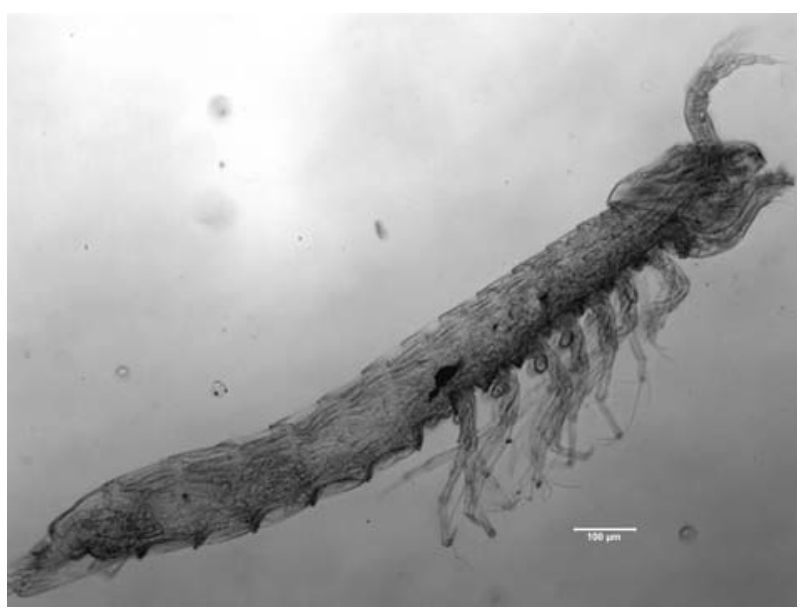

Fig. 2.- Iberobathynella (Espanobathynella) burgalensis $\mathrm{n}$. sp., female.

Fig. 2.- Fotografía óptica de una hembra de Iberobathynella (Espanobathynella) burgalensis n. $\mathrm{sp}$.

SPeCIES: I. (E.) espaniensis Serban et Comas i Navarro, 1978; I. (E.) magna Camacho et Serban, 1998, I. (E.) cantabriensis Camacho et Serban, 1998 and $I$. (E.) burgalensis n. sp.

\section{Iberobathynella (Espanobathynella) burgalensis n.sp.} (figs. 1-5)

Material eXamined. Ojo Guareña cave, Cornejo (Burgos) (largest cave in Spain) (Coordinates X: 448875, Y: 4764802, Z: 673). Collected by PASCALIS team (25 september 2004). Small temporary pool. Type series comprising male Holotype (MNCN 20.04/6062) (Fig. 1) and seven paratypes (MNCN $20.04 / 6063$, four males and three females).

DESCRIPTION. Body: total length $1.25-1.47 \mathrm{~mm}$ (males; holotype $1.47 \mathrm{~mm}$; see Fig. 1) $1.38-1.61$ $\mathrm{mm}$ (females; Fig. 2). Body elongated, somites progressively wider towards posterior end of body. Head of similar length and width.

Antennule (A.I) (Fig. 3A): 7-segmented; not sexually dimorphic; first four segments combined longer than the last three combined; setation as in figure $3 \mathrm{~A}$ (segment 5 with two aesthetascs; segments 5 and 6 with three aesthetascs each). Antenna (A.II) (Fig. 3B): 3-segmented, last segment the longest, with two smooth and one plumose terminal setae and a small, shorter seta midway; first two segments without setae. Labrum (Lb.) (Fig. 3D): with eight main teeth, and two lateral teeth at each site. Mandible (Md) (Figs. 3E, 3F): pars incisiva with seven well-developed teeth; pars molaris with 

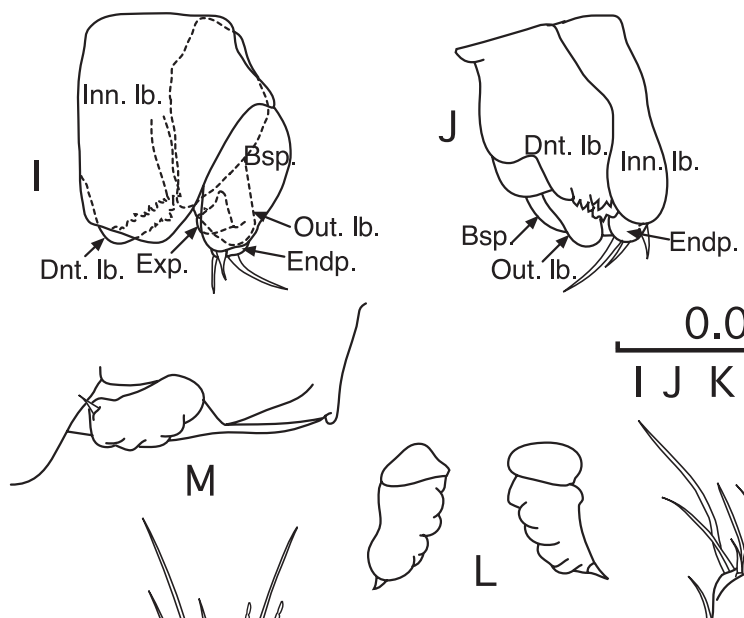

$$
\frac{0.05}{\mathrm{IJKLM}}
$$
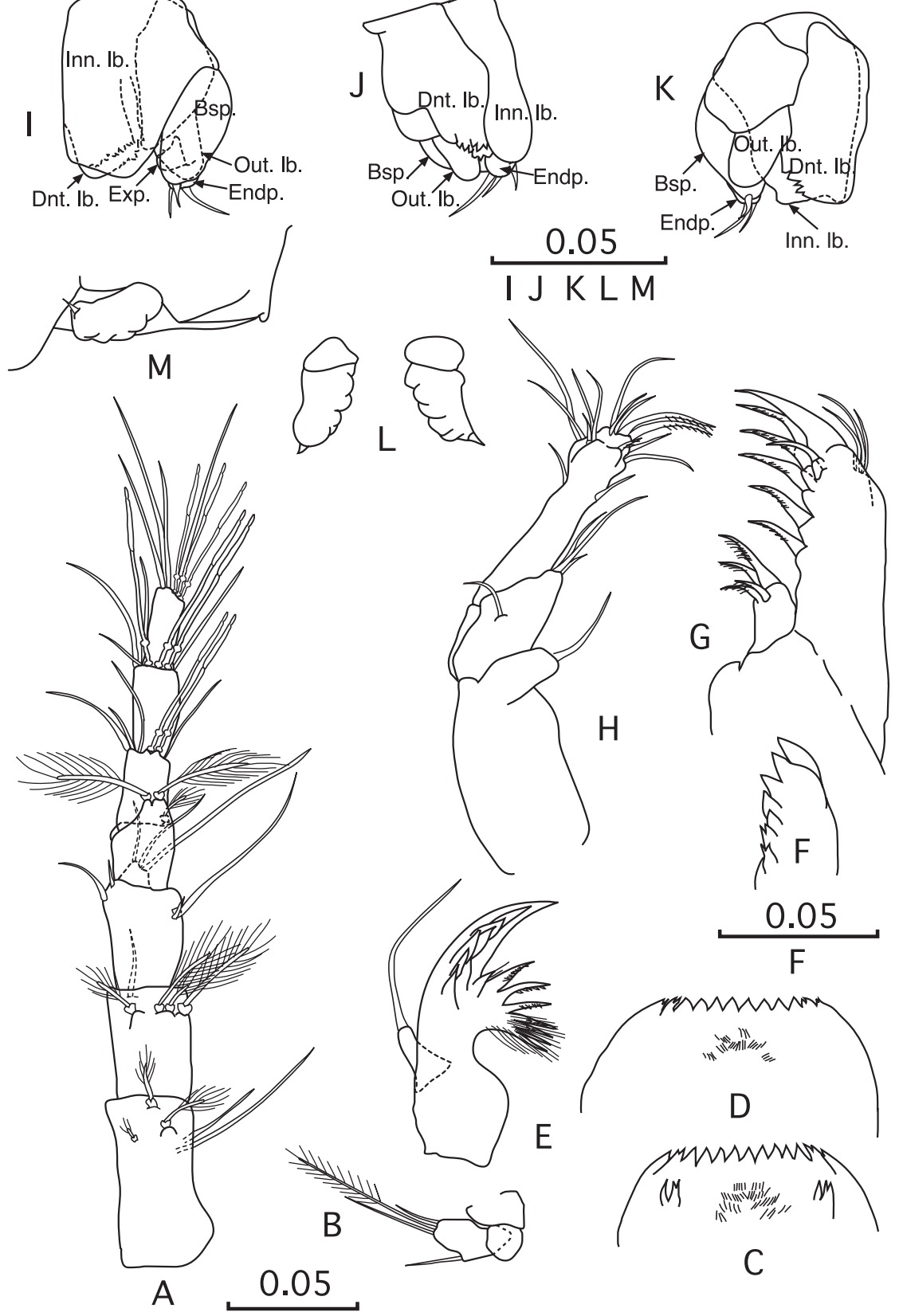

$\mathrm{F}$

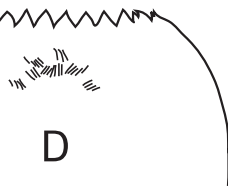
M

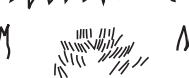

$\mathrm{C}$

Fig. 3.-Iberobathynella (Espanobathynella) burgalensis n.sp., male holotype. A: Antennule; B: Antenna; C: Labrum female; D: labrum; E: Mandible; F: pars incisiva of Mandible (dorsal view); G: Maxillule; H: Maxilla; I: male Thoracopod 8 (latero-internal view); J: male Thoracopod 8 (frontal view); K: male Thoracopod 8 (latero-external view); L: female Thoracopod 8 (ventral view) and M: Thoracopod 8 female (latero-internal view). Abbreviature used: Inner lobe (Inn. Lb.); basipod (Bsp.); dentate lobe (Dnt. Lb.); exopod (Exp.); basipod (Bsp.); outer lobe (Out. Lb.) and endopod (Endp.). (Scale in mm).

Fig. 3.- Iberobathynella (Espanobathynella) burgalensis n.sp., holotipo macho. A: Antenula; B: Antena; C: Labro de la hembra; D: labro; E: Mandíbula; F: pars incisiva de la mandíbula (vista dorsal); G: maxilula; H: maxila; I: pereiopod 8 macho (vista latero-interna); J: pereiopodo 8 macho (vista frontal); K: pereiopodo 8 macho (vista latero-externa); L: pereiopodo 8 hembra (vista ventral) y M: pereiopodo 8 hembra (vista latero-interna). Abreviaturas usadas: lóbulo interno (Inn. Lb.); basipodio (Bsp.); lóbulo dentado (Dnt. Lb.); exopodio (Exp.); lóbulo externo (Out. Lb.) y endopodio (Endp.) (Escale en mm). 


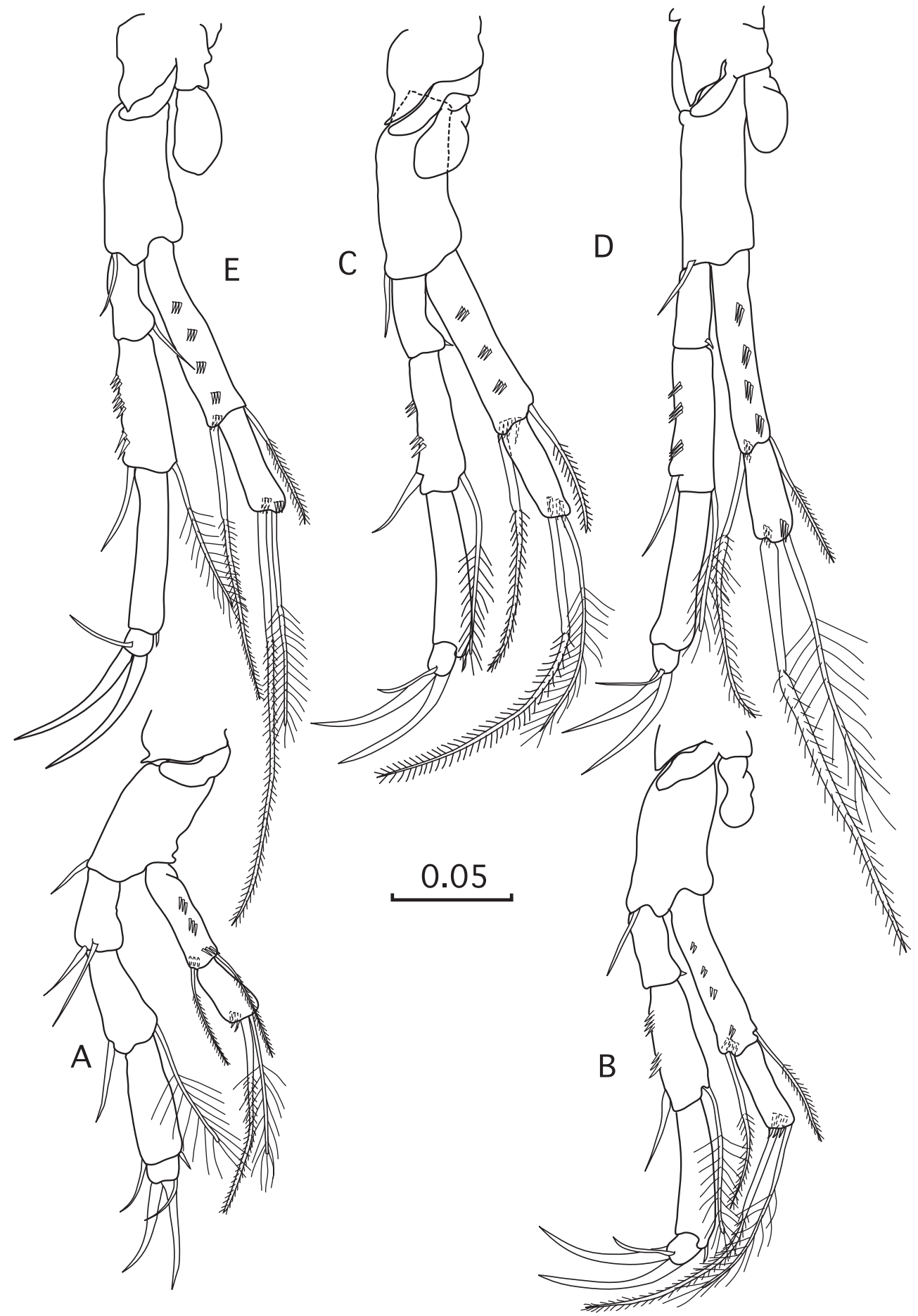

Fig. 4.-I. (E.) burgalensis n.sp., male holotype. A: Thoracopod 1; B: Thoracopod 2; C: Thoracopod 3; D: Thoracopod 4 and E: Thoracopod 5. (Scale in $\mathrm{mm}$ ).

Fig. 4.-I. (E.) burgalensis n.sp., holotipo macho. A: pereiopodo 1; B: pereiopodo 2; C: pereiopodo 3; D: pereiopodo 4 and E: pereiopodo 5. (Escale en $\mathrm{mm}$ ). 


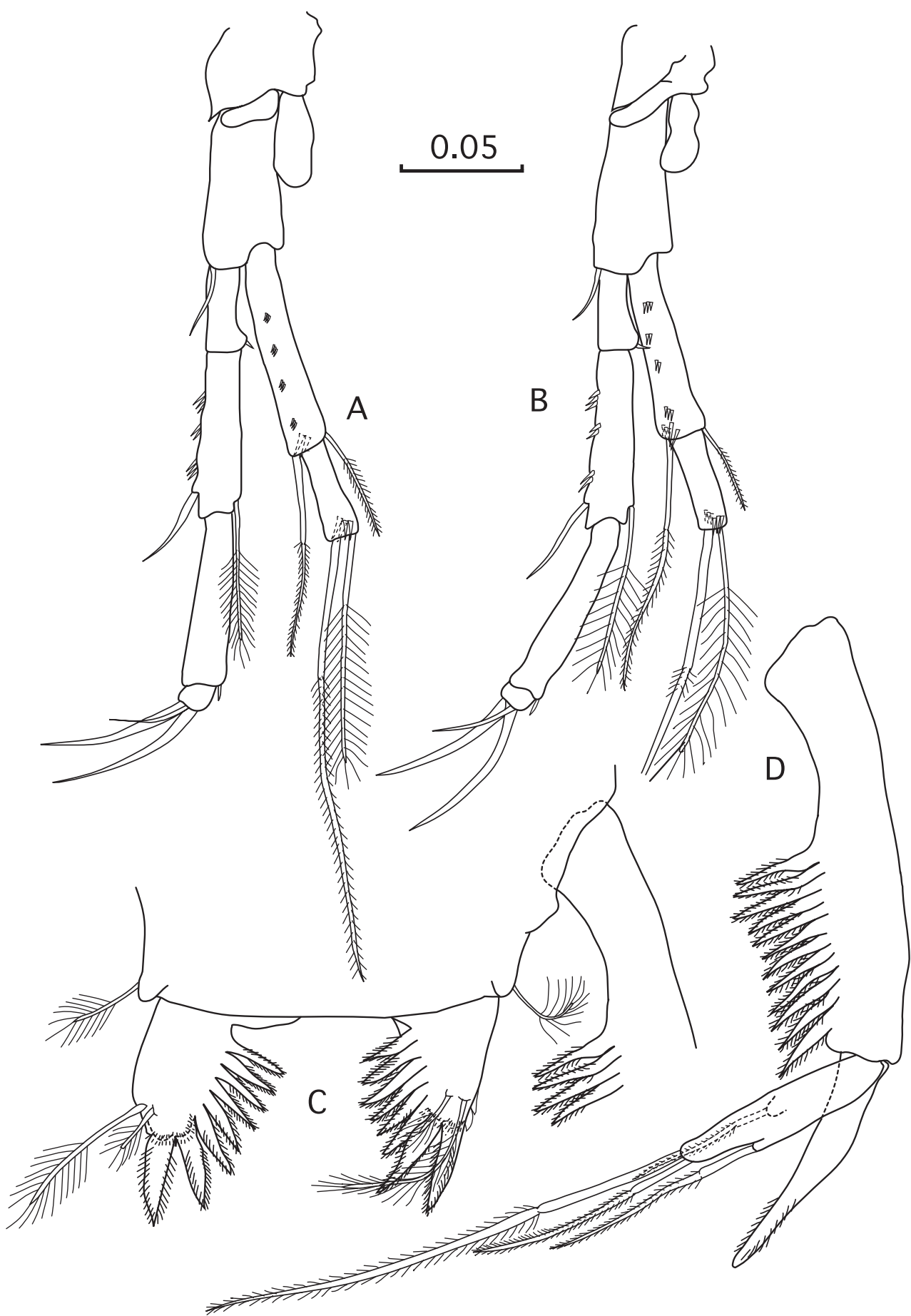

Fig. 3.-I. (E.) burgalensis n.sp., male holotype. A: Thoracopod 6; B: Thoracopod 7; C: Pleotelson and furca (dorsal view); D: uropod (latero-internal view). (Scale in $\mathrm{mm}$ ).

Fig. 3.-I. (E.) burgalensis n.sp., holotipo macho. A: pereiopodo 6; B: pereiopodo 7; C: Pleotelson y furca (vista dorsal); D: urópodo (vista latero-interna). (Escala en $\mathrm{mm}$ ). 
nine teeth, seven strong distal and two small joined proximal teeth densely setulose; mandibular palp not exceeding pars incisiva in length. Maxillule (Mx.I) (Fig. 3G): proximal endite with four claws (spines of different sizes); distal endite with seven claws, two distal smooth, rest denticulate; three smooth setae subterminally on outer distal margin. Maxilla (Mx.II) (Fig. 3H): 3-segmented, with one seta on proximal segment; segment 2 with two long and one shorter setae distally, plus one additional seta on inner margin; segment 3 elongated, with 15 setae. Thoracopods 1-7 (Th.1-Th.7) (Figs. 4A to 4E, 5A, 5B): well-developed, gradually increasing in length from 1 to 5 (Figs. 4A to 4E), last three similar in size; well-developed epipodite on 2 to 7 , measuring not more than half the length of the basipod; basipod with one seta on outer distal angle. Thoracopod 1 (Fig. 4A): short, exopod 2-segmented in all completely developed specimens, with two setae on each segment, setae on second segment one plumose, the other barbed, and with ctenidia on distal margin of segment; endopod 4-segmented: first segment with two smooth ventral setae, second with one smooth and one plumose setae, third with two setae, one small and smooth and the other tiny, terminal segment with two claws of similar length and one seta. Thoracopods 2 to 7 (Figs. 4B to 4E, 5A, 5B): exopod 2-segmented, segment 1 with two terminal setae, one short and smooth, the other long and barbed; segment 2 with two terminal setae, one barbed, the other plumose; ctenidia at distal margin of both segments; endopod 4-segmented, segment 1 short and without setae, but with one small outer spine (on the Th 5 this spine is really a small seta, Fig. 4E); segment 2 with two groups of medial ctenidia and one plumose and one smooth seta; segment 3 with one tiny seta; last segment with one seta and two strong claws of similar length. In all thoracopods the two segments of the exopod combined (the first segment is twice the second in length) are sligthly longer than the first two segments of the endopod combined. Thoracopod 8 (Th. 8), male (Figs. 3I-K): massive, subrectangular; basal region massive; inner lobe rectangular and completely integrated into the basal region, exceeding the distal end of dentate lobe; dentate lobe with eight to ten teeth; basipod elongated with one short seta distally, endopod small, with two setae; exopod small with two small teeth; outer lobe not fused with basipod and almost triangular. Thoracopod 8, female paratype (Figs. 3L, $3 \mathrm{M})$ : not very reduced and with wrinkled cuticle, with one small terminal tooth. Dorsal margin of pleotelson (Fig. 5C): anal operculum not pronoun- ced; one barbed seta at each lateral angle. Uropod (Fig. 5D): sympod almost twice the length of endopod and almost five times longer than wide, with twelve similar barbed spines, the distal slightly longer (than the rest or the others), which are of equal length and are located on the segment's distal half; endopod longer than exopod, without setae; exopod with two terminal and two subterminal barbed setae, and no basal plumose seta (always present in the other species of the genus). Furca (Fig. 5C): with eight barbed spines (the two terminal ones slightly longer and thicker than the rest); two plumose setae, one long and another shorter, placed distally.

VARIABILITY. The female is similar to the male, except for the thoracopod 8 and the number of main teeth of the labrum (Fig. 5C), nine in all females studied and eight in all males. The variability affects: the number of teeth on the pars incisiva of the Md. (the specimens studied have between seven and nine teeth); the number of spines on the sympod of the uropod (10 to 12); and the number of spines on the furca (6 to 8 ). The holotype (male) is the only specimen studied that has a small dorsal seta on segment 1 of the endopod of the Th. 5 (in the other legs this segment has a small dorsal spine). In the other specimens all legs (except the Th. 1) have a small dorsal spine on the first segment of the endopod.

The species of subgenus Iberobathynella (Iberobathynella) Schminke, 1973 have a seta on the first segment of the endopod of Th. 2 to 7 . The other species of genus Iberobathynella do not have it.

ETYMOLOGY. The species name is derived from the province of Burgos, in the North of Spain which is full of caves and where many different species of Bathynellacea have been found.

REMARKS. The new species belongs to the subgenus I. (Espanobathynella) Camacho et Serban, 1998 (see Table 2). It has seven teeth on the distal endite of the maxillule combined with: one seta on segment one of the Mx.II; 2 setae on segment one and three setae on segment 2 of the endopod of the Th. 1; no seta developed on segment one of the endopodod of Ths. 2 to 7; and the external lobe of Th 8 male has the sloping main axis. There are three generic characters that have to be modified in the diagnosis (Camacho et Serban, 1998) due to the incorporation of the new species: pars incisiva of the Md with 4 to 7 teeth, pars molaris with 6 to 9 teeth and endopod of the uropod with 1 or 0 setae.

The subgenus I. (Espanobathynella) has one species, I. (E.) magna Camacho et Serban, 1998 (num- 


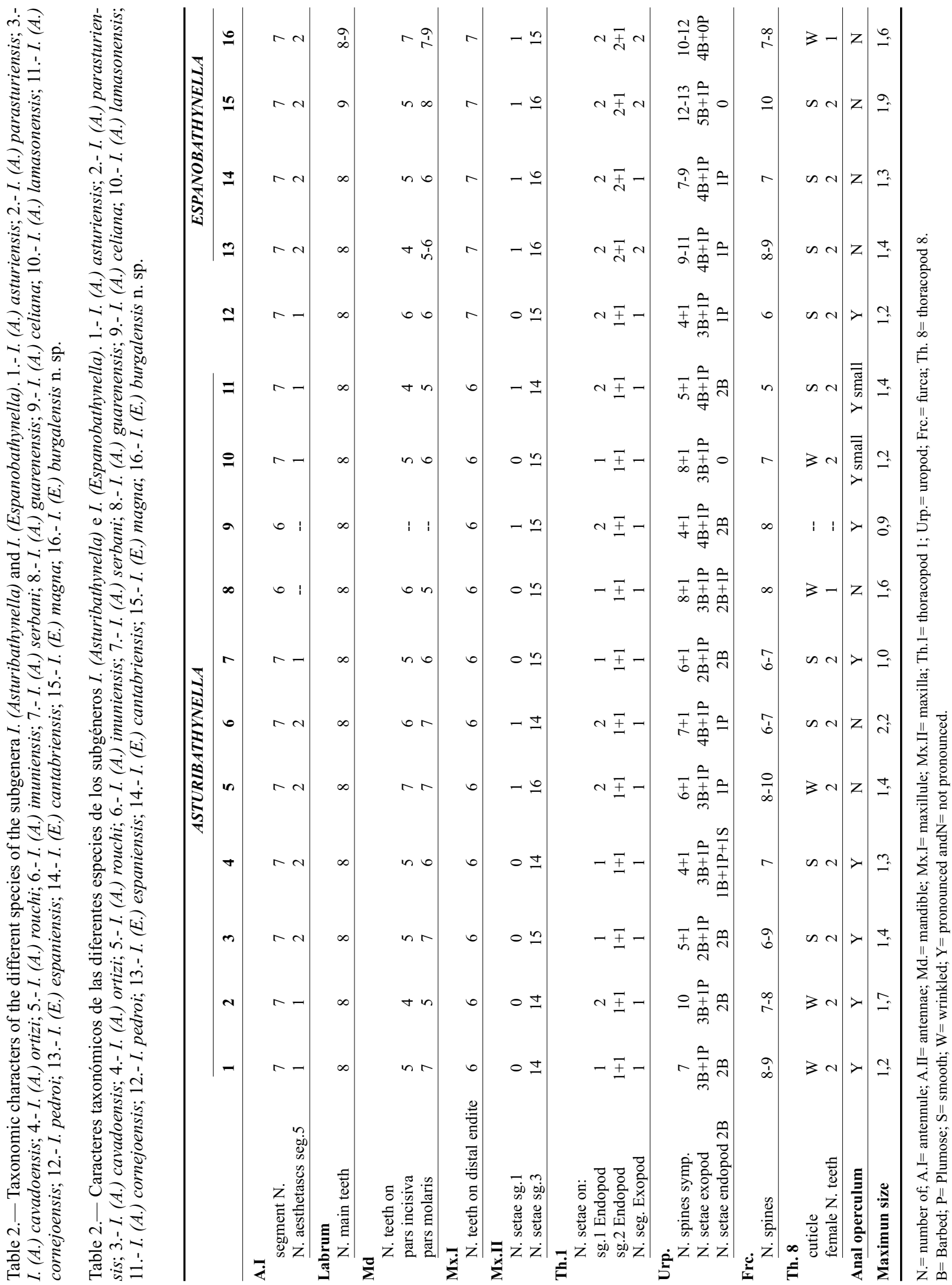




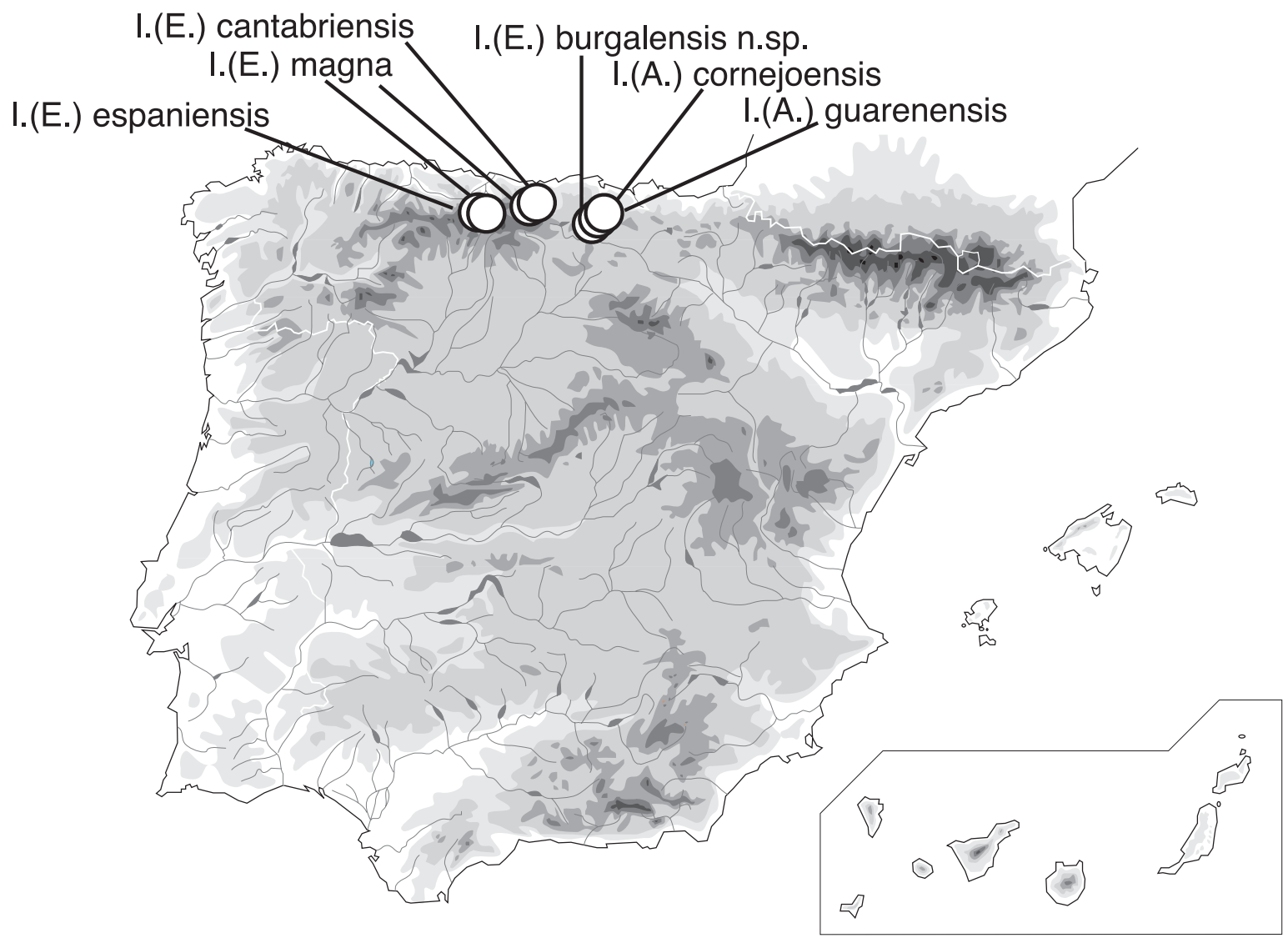

Fig. 4.- Distribution of Iberobathynella (Espanobathynella) burgalensis n.sp. and the $I$. (E.) genus in the Iberian Peninsula. The distribution of $I$. (A.) guarenensis and $I$. (A.) cornejoensis is also shown.

Fig. 4.- Distribución del género Iberobathynella (Espanobathynella) y de la nueva especie I. (E.) burgalensis en la Península Ibérica. Se muestra, también, la distribución de las especies $I$. (A.) guarenensis y I. (A.) cornejoensis.

ber 15 in table 2) that has nine main teeth on the labrum, like the females of the new species. In addition, both have the same number of teeth on the pars molaris of the Md. But $I$. (E.) burgalensis n.sp has more teeth on the pars distalis of the Md. than any other species in the genus, and less setae on the third segment of the MxII (15 only). The new species has 2 segments on the exopod of the first thoracopod, as I. (E.) magna and I. (E.) espaniensis Serban et Comas, 1978. But $I$. (E.) burgalensis n.sp shows four unique characters in the subgenus: absence of basal seta on the exopod of uropod; absence of seta on the endopod of uropod, wrinkled cuticle in the female Th. 8, and only one spine on the latter Th.

Several species of the subgenus Asturibathynella Camacho et Serban, 1998 (viz. I. (A.) asturiensis
Serban et Comas, 1978; I. (A.) parasturiensis Camacho et Serban, 1998; I. (A.) rouchi Camacho \& Coineau, 1987; I. (A.) guarenensis Camacho, 2003b and I. (A.) lamasonensis Camacho, 2005) (table 2) have a female Th. 8 with a wrinkled cuticle like the new species. Other characters shared between the new species and other members of the subgenus are summarized in table 2. For example, the absence of setae on the endopod of the uropod (shared with $I$. (A.) cornejoensis Camacho, 2005). But members of the subgenus never have seven teeth on the distal endite of the Mx.I as do the species of the subgenus Espanobathynella and Iberobathynella (Camacho et Serban, 1998).

The new species is easily recognised based on the combination of carácter states shown in table 
2. In addition, the overall appearance and size of the different lobes of the male thoracopod 8 , are also diagnostic.

\section{Distribution}

Figure 6 shows the distribution of the new species and also the distribution of the rest of species in the subgenus Espanobathynella found in the North of the Iberian Peninsula.

The new species of Iberobathynella was found in Burgos where no other species of the subgenus Espanobathynella occur (Camacho, 2003c). To date, 21 species of this endemic genus are known on the Iberian Peninsula. Mainly concentrated in the north and west; in the south and east they are known from two localities only.

The subgenus Espanobathynella is restricted to a small part of Cantabria and Asturias (Eastern part of Asturias, Picos de Europa and the Sierra de la Collada, between Asturias and Cantabria) (see Fig. 6). I. (E.) espaniensis inhabits only the type locality, Cueva del Infierno (Covadonga, Asturias) whereas $I$. (E.) magna shares the same type locality and also occupies numerous caves in the Sierra de la Collada (Asturias and Cantabria). I. (E.) cantabriensis dwells in several caves of the Sierra de la Collada. The new species lives in the Ojo Guareña cave, where the species $I$. (A.) guarenensis is also found, but in different parts of this vast cave system. Another species, I. (A.) cornejoensis, is found in another cave connected to the main cave and in the interstitial environment of the river Trema (Cornejo) that flows over the Ojo Guareña system.

\section{ACKNOWLEDGEMENTS}

We gratefully acknowledge C. Puch, F. Molinero, J. Robador, A. De Juan, F. Lázaro, A. G. Valdecasas and J. Rodriguez, who helped us in different ways. We thank Mark Creb who helped us with the English translations. This work was supported by project EVK2-CT-2001-00121 (European Projects PASCALIS) and Convenio Junta de Castilla y León and CSIC.

\section{References}

Braga, J. M., 1949. Un Bathynellidae (Crust. Syncarida) du Portugal (Parabathynella lusitanica $\mathrm{n}$. sp.). Publicaçoes do Instituto de Zoologia "Dr. Augusto Nobre”, 40: 1-15.
Braga, J. M., 1960. Sur une Parabathynella (Crust. Syncarida) nouvelle du Portugal. Publicaçoes do Instituto de Zoologia "Dr. Augusto Nobre", 75: 9-22.

CAMAcho, A. I., 1987. A new subterranean syncarid (Crustacea) from Spain: Iberobathynella imuniensis n.sp. (Bathynellacea, Parabathynelidae). Archiv für Hydrobiologie, 111(1): 137-149.

Camacho, A. I., 1989. A new species of the "mateusi" group: Iberobathynella ortizi sp. n. (Crustacea, Syncarida, Parabathynellidae). Zoologica Scripta, 18(3): 405-410.

CAmacho, A. I., 2003b. Four new species of groundwater crustaceans (Syncarida, Bathynellacea, Parabathynellidae) endemic to the Iberian Peninsula. Journal of Natural History, 37: 2885-2907.

CAMACHO, A. I., 2003c. An overview of the distribution of the Parabathynellidae (Crustacea, Syncarida, Bathynellacea) on the Iberian Peninsula and Balearic Islands. Graellsia, 59(1): 63-78.

CAMAcho, A. I., 2005. Expanding the taxonomic conundrum: three new species of groundwater crustacean (Syncarida, Bathynellacea, Parabathynellidae) endemic to the Iberian Peninsula. Journal of Natural History, 39(21): 1819-1838.

Camacho, A. I., Bello, E. \& Estabrook, G. F., 1997. A statistical approach to the evaluation of characters to estimate evolutionary relationships among the species of the aquatic subterranean genus, Iberobathynella (Crustacea, Syncarida). Biological Journal of the Linnean Society, 60: 221-241.

CAmacho, A. I. \& CoIneau, N., 1987. Un nouveau représentant du genre Iberobathynella Schminke en Espagne: I. rouchi n. sp. (Syncarida, Bathynellacea). Remarques phylogénétiques et paléobiogéographiques, Stygologia, 3(2): 125-137.

Camacho, A. I. \& Serban, E. 1998. Tribu des Iberobathynellini nov. Diagnoses des taxa nouveaux (Parabathynellidae, Bathynellacea, Podophallocarida). Travaux de l'Institut de Spéologie Emile Racovitza, XXXIV (1995): 15-75.

CAMACHO, A. I. \& SERBAN, E. 2000. Revisión del grupo Iberobathynella (Iberobathynella) Schminke, 1973 (Crustacea, Syncarida, Parabathynellidae) endémico de la Península Ibérica. Graellsia, 56: 35-48.

Camacho, A. I., Serban, E. \& Guil, N., 2000. Phylogenetical review and biogeographic remarks on the interstitial and subterranean freshwater iberobathynell (Crustacea, Syncarida, Parabathynellidae). Journal of Natural History, 34: 563-585.

Galhano, M. H., 1970. Contribuçao para o conhecimiento de fauna intersticial em Portugal. Parabathynella lusitanica valbonensis ssp. n. Publicaçoes do Instituto de Zoologia "Dr. Augusto Nobre", 110: 77-82 y 148-153.

GuIL, N. \& CAMACHO, A. I., 2001. Historical biogeography of Iberobathynella (Crustacea, Syncarida, 
Bathynellacea), an aquatic subterranean genus of Parabathynellids, endemic to the Iberian Peninsula. Global Ecology and Biogeography, 10: 487-501.

Noodt, W. \& Galhano, M. H., 1969. Studien und Crustacea subterranea (Isopoda, Syncarida, Copepoda) aus dem Norden Portugal. Publicaçoes do Instituto de Zoologia "Dr. Augusto Nobre", 107: 9-75.

Schminke, H. K., 1973. Evolution, System und Verbreitungsgeschichte der Familie Parabathynellidae (Bathynellacea, Malacostraca). Akademie der Wissenschaften und der Literatur Mainz, Mathematisch-Naturwissenschaftliche Klasse, Mikrofauna des Meeresboden, 24: 1-192.
Serban, E. \& Comas i Navarro, J. C., 1978. Contribution à la connaissance du genre Iberobathynella Schminke: I. asturiensis n. sp. et I. espaniensis n. sp., nouvelles espèces d'Espagne (Bathynellacea, Parabathynellidae). Travaux de l'Institut de Spéologie "Emile Racovitza”, XVII: 13-37.
Recibido, 5-IV-2005 Aceptado, 14-VI-2005 Publicado, 14-VII-2005 